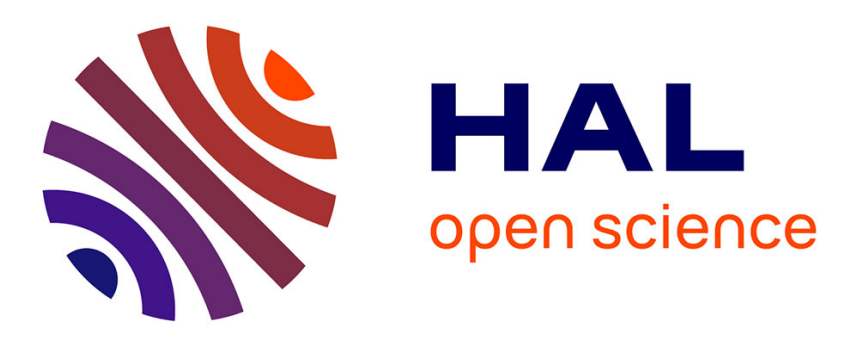

\title{
Host range expansion of honey bee Black Queen Cell Virus in the bumble bee, Bombus huntii
}

\author{
Wenjun Peng, Jilian Li, Humberto Boncristiani, James Strange, Michele
} Hamilton, Yanping Chen

\section{- To cite this version:}

Wenjun Peng, Jilian Li, Humberto Boncristiani, James Strange, Michele Hamilton, et al.. Host range expansion of honey bee Black Queen Cell Virus in the bumble bee, Bombus huntii. Apidologie, 2011, 42 (5), pp.650-658. 10.1007/s13592-011-0061-5 . hal-01003597

\section{HAL Id: hal-01003597 \\ https://hal.science/hal-01003597}

Submitted on 1 Jan 2011

HAL is a multi-disciplinary open access archive for the deposit and dissemination of scientific research documents, whether they are published or not. The documents may come from teaching and research institutions in France or abroad, or from public or private research centers.
L'archive ouverte pluridisciplinaire HAL, est destinée au dépôt et à la diffusion de documents scientifiques de niveau recherche, publiés ou non, émanant des établissements d'enseignement et de recherche français ou étrangers, des laboratoires publics ou privés. 


\title{
Host range expansion of honey bee Black Queen Cell Virus in the bumble bee, Bombus huntii
}

\author{
Wenjun Peng ${ }^{1}$, Jilian $\mathrm{Li}^{1}$, Humberto Boncristiani ${ }^{2}$, James P. Strange ${ }^{3}$, \\ Michele Hamilton $^{2}$, Yanping CHEN ${ }^{2}$
${ }^{1}$ Key Laboratory of Pollinating Insect Biology of the Ministry of Agriculture, Institute of Apicultural Research, Chinese Academy of Agricultural Science, Xiangshan, Beijing, China
${ }^{2}$ USDA-ARS Bee Research Lab, BARC-East Bldg, 476,, Beltsville, MD 20705, USA
${ }^{3}$ USDA-ARS Pollinating Insects, Biology, Management and Systematics Laboratory, Utah State University, BNR 255, Logan, UT 84322-5310, USA

Received 27 September 2010 - Revised 18 January 2011 - Accepted 30 January 2011

\begin{abstract}
Here we provide the first evidence that Black Queen Cell Virus (BQCV), one of the most prevalent honey bee viruses, can cause an infection in bumble bees, Bombus huntii, and that the BQCV infection could spread to different tissues of bumble bees. The detection of negative strand RNA of BQCV, an indicator of active virus replication, in the gut of $B$. huntii suggests that virus particles replicate within the gut and then cross the gut lining to other tissues through hemolymph circulation. The observation of active replication of the $\mathrm{BQCV}$ in the gut, together with the fact that BQCV was more widespread in the body of field-collected bees than that of lab-reared bees, implies a possible association between the foraging activities of bumble bees and virus transmission. The fact that bumble bees and honey bees are able to share nectar and pollen resources in the same field suggests that geographical proximity of two host species could play a role in host range breadth of BQCV.
\end{abstract}

host range / bumble bee / Bombus huntii / Black queen cell virus

\section{INTRODUCTION}

Bumble bees (Order: Hymenoptera, Family: Apidae, Genus: Bombus) have long been recognized as important pollinators of crops, particularly in temperate zone plants (Proctor et al. 1996; Velthuis and van Doorn 2006). Like honey bees (Apis mellifera L.), bumble bees forage for nectar and pollen from a wide range of plants as food for the entire colony and act as pollinators transferring pollen between plants

Corresponding author: Y. Chen,

Judy.Chen@ars.usda.gov

Wenjun Peng and Jilian Li contributed equally in this work.

Manuscript editor: Peter Rosenkranz
(Heinrich 2004). The interactions by sharing the same nectar and pollen resources in the field have been documented for two bee species (Reader et al. 2005; Evans and Spivak 2006; Dohzond and Yokoyama 2010). Compared to honey bees, bumble bees have longer tongues (glossa) which allow them to forage more efficiently from flowers with long and narrow corollas. The specialized behavior, termed "buzz pollination," and the branched hair that covers the entire bodies of bumble bees facilitate efficient collection and transfer of pollen from flower to flower. Under certain circumstances, bumble bees are considered superior in pollinating to honey bees because bumble bees can pollinate plants on rainy, cool days, when honey bees stay inactive 
within the hive (Whitman 2007). Due primarily to their efficiency in pollinating solanaceous crops, some species of bumble bees have been commercially reared for the pollination of the crops, especially greenhouse tomatoes, peppers, and eggplants. Bombus huntii, a bumble bee species native to western North America, is a prominent pollinator in agroecosystems (Hobbs 1967) and is easily reared in the laboratory (Strange 2011).

From a health perspective, host range breadth of pathogens may have important consequences for the increase of pathogen virulence, the emergence of new diseases, and the reduction of biodiversity. Studying the occurrence of multiple host infection of pathogens could have an important implication for understanding pathogen population structure and diversity, host-pathogen interactions, and evolutionary dynamics of diseases (Schmid-Hempel 2001; Brown et al. 2003). Like their relatives, the honey bees, bumble bees face threats from numerous pathogens, including bacteria, fungi, protozoa, and viruses and some species have been experiencing population declines (Cameron et al. 2011). Previous studies have shown that both honey bees and bumble bees can share the same pathogens (Colla et al. 2006). For instance, Deformed Wing Virus, one of the most common and prevalent viruses found in honey bees (reviewed in Chen and Siede 2007), was demonstrated to cause wing deformities in bumble bees (Genersch et al. 2006). Other honey bee viruses, including Acute Bee Paralysis Virus and Kashmir Bee Virus were found to be equally capable of infecting different species of bumble bees (Bailey and Gibbs 1964; Anderson 1991). In order to gain further insight into the movement of pathogens between honey bees and bumble bees, the infection of another one of the most prevalent honey bee virus, Black Queen Cell Virus (BQCV), a RNA virus classified within the family Dicistroviridae genus Cripavirus (Mayo 2002) and was found to cause a significant disease in developing queen larvae and pupae (Bailey and Woods 1977; Anderson 1993), was investigated in bumble bees in the present study.

\section{MATERIALS AND METHODS}

\subsection{Insects}

Three groups of bumble bees, B. huntii, were used in the study: (1) male $B$. huntii reared in the lab, (2) worker $B$. huntii reared in the lab, and (3) male $B$. huntii collected from the field. Bumble bees were collected from the USDA-ARS Pollinating Insect Research Unit, Logan, UT. Lab-reared males and workers came from a colony originating from a queen bee collected foraging in the spring. The colony was reared according to Strange (2011) until workers and males were present. Briefly, the colony was fed syrup of $25 \%$ sugars (sucrose, glucose, and fructose) and pollen, removed and collected from pollen traps affixed to honey bee colonies, until the colony reached a size exceeding 100 individuals. Individual worker bees were then removed from the lab-reared colony before the bees were permitted to forage freely. Field-collected males were captured with an entomological aerial net while foraging on raspberry (Rubus sp.). No female $B$. huntii were observed during the field collection, likely due to the seasonality of worker production in bumble bees. Each group of captured bees was transferred into a cage which was provisioned with sugar syrup and mailed alive to the USDA Bee Research Laboratory, Beltsville, MD for the molecular analysis.

\subsection{Tissue dissection}

Different groups of $B$. huntii were used for tissue dissection. Ten bees were dissected for each group. Each live bumble bee was individually fixed on the wax top of a dissecting dish with insect pins. Hemolymph was collected with a micropipette tip by making a small hole on the roof of the bee's thorax with a needle to make it bleed. About $20 \mu \mathrm{l}$ of hemolymph was collected from each bee. Following hemolymph collection, the legs, wings, antennae, and eyes were cut off and then the main body of the bee was opened with scissors. Tissues of the brain, fat bodies, salivary glands, gut, nervous systems, trachea, and food glands were separated and pulled out of the body with forceps under a dissecting microscope. To prevent possible contam- 
ination with hemolymph, all tissues were rinsed with $1 \times$ phosphate-buffered saline three times and twice with nuclease-free water and the washing solution was changed every time for each tissue. Individual tissues were subjected to subsequent RNA extraction immediately.

\subsection{RNA extraction}

Total RNA samples were individually extracted from 12 different tissues of the bumble bees using Trizol reagent according to the manufacturer's specifications (RNA extraction kit; Invitrogen, Carlsbad, CA). The resultant RNA pellets were re-suspended in UltraPure DNase/RNase-Free Distilled Water (Invitrogen) in the presence of Ribonuclease Inhibitor (Invitrogen). RNA samples were stored at $-80^{\circ} \mathrm{C}$ prior to molecular detection for BQCV.

\subsection{RT-PCR}

All RNA samples were tested for the presence of BQCV using the Access RT-PCR system (Promega, Madison, WI) according to the manufacturer's instructions. The primers used in the study were based on primers published by Benjeddou et al. (2001) and generated PCR fragments of $702 \mathrm{bp}$. The reaction mixture contained: $1 \times \mathrm{AMV} / \mathrm{Tfl}$ reaction buffer, $0.2 \mathrm{mM}$ each deoxynucleotide triphosphate, $1 \mu \mathrm{M}$ of sense primer, $1 \mu \mathrm{M}$ of antisense primer, $2 \mathrm{mM} \mathrm{MgSO}_{4}, 0.1 \mathrm{U}$ AMV reverse transcriptase, $0.1 \mathrm{U}$ T $f l$ DNA polymerase, and $500 \mathrm{ng}$ total RNA in a total volume of $25 \mu \mathrm{l}$. Amplification was undertaken with the following thermal cycling profiles: one cycle at $48^{\circ} \mathrm{C}$ for $45 \mathrm{~min}$ for reverse transcription; one cycle of $95^{\circ} \mathrm{C}$ for $2 \mathrm{~min}$; 40 cycles at $95^{\circ} \mathrm{C}$ for $30 \mathrm{~s}, 55^{\circ} \mathrm{C}$ for $1 \mathrm{~min}$, and $68^{\circ} \mathrm{C}$ for $2 \mathrm{~min}$; and one cycle of $68^{\circ} \mathrm{C}$ for $7 \mathrm{~min}$. Negative (water) and positive controls (recombinant plasmid DNA with BQCV insert into pCR 2.1 vector) were included in each run of the RT-PCR reaction. PCR products were electrophoresed in $1 \%$ agarose gel containing $0.5 \mathrm{ug} / \mathrm{ml}$ ethidium bromide and visualized under UV light. To prevent possible contamination of PCR products, the RT-PCR reaction mixture was prepared in a PCR chamber (PLAS, Lansing, MI) and the gel electrophoresis was conducted in a separate room.

\subsection{Strand-specific RT-PCR}

In order to determine whether the bumble bee was a biological host to support replication of BQCV, strand-specific RT-PCR was conducted for the presence of negative-stranded RNA of BQCV in bumble bees. The cDNA which is complementary to the negative strand RNA of BQCV was synthesized from total RNA extracted from different tissues of bumble bees with Tag-BQCV-sense primer (position 81328151) (5'-agcctgcgcacgtggTCAGGTCGGAATAATCTCGA-3') using SuperScript III Reverse Transcriptase (Invitrogen, Carlsbad, CA). The sequence of Tag is shown in lowercase and was published by Yue and Genersch (2005). The synthesized cDNAs were then purified twice using MinElute PCR purification kit and MinElute Reaction Clean kit to remove short fragments of oligonucleotides and residues of enzymatic reagents to prevent amplification of non-strand-specific products (Boncristiani et al. 2009), respectively. The PCR amplification of cDNA was conducted with a Tag (3'AGCCTGCGCACCGTGG-5') and BQCV-antisense primer (position 8527-8550) (5'-GCAACAAGAAGAAACGTAAACCAC-3') in the following thermal cycling profile: $94^{\circ} \mathrm{C}$ for $2 \mathrm{~min} ; 35$ cycles at $94^{\circ} \mathrm{C}$ for $30 \mathrm{~s}, 55^{\circ} \mathrm{C}$ for $30 \mathrm{~s}$, and $72^{\circ} \mathrm{C}$ for $1 \mathrm{~min}$; and an extension at $72^{\circ} \mathrm{C}$ for $10 \mathrm{~min}$. A PCR fragment of $420 \mathrm{bp}$ was expected to be generated. A positive control generated by cloning the BQCV-specific fragment (position 7848-8550) into the pCR2.1 vector using the Invitrogen original TA cloning kit was included in each run of the reaction. The amplification products of the negative strand RNA of BQCV were electrophoresed on ethidium bromidecontaining low melting agarose gel (Invitrogen) and excised and purified using the Wizard PCR Prep DNA Purification System (Promega, Madison, WI). The nucleotide sequences of the purified fragments were determined from both forward and reverse directions. The sequence data of each virus fragment were analyzed using the BLAST server at the National Center for Biotechnology Information, NIH.

\subsection{Phylogenetic analysis}

PCR bands specific for BQCV from conventional RTPCR were purified using the Wizard PCR Prep DNA 
Purification System (Promega, Madison, WI) and sequenced to confirm the specificity of RT-PCR and strand-specific RT-PCR assays used in the study. The sequences of $\mathrm{BQCV}$ from bumble bees in the present study were compared with the sequences of BQCV from honey bees retrieved from GenBank and originating from different countries including PA, USA (GenBank Acession no. NC_003784; Leat et al. 2000), Korea (GenBank Acession no. FJ603458), Brazil (EU292211), Uruguay (DQ364629), Jordan (GU459315), and Germany (AF521640). The equivalent sequences of Israeli Acute Paralysis Virus (GenBank Acession no. NC_009025) were used as an outgroup. Sequences were aligned using MegAlign (DNASTAR Lasergene software program, Madison, WI). Sequences that could not be aligned unambiguously at both $3^{\prime}$ and $5^{\prime}$ ends were truncated. Phylogenetic analysis was conducted using ClustalW (Chenna et al. 2003). Maximum Parsimony under a heuristic search was used to construct the phylogenetic relationship. Phylogenies were assessed by the bootstrap replication $(N=500$ replicates). Numbers in the nodes correspond to bootstrap values and bootstrap values of $>50 \%$ were regarded as providing evidence for the phylogenetic grouping.

\section{RESULTS}

The results of the RT-PCR assay showed that BQCV infects bumble bees. For B. huntii males collected from the field, BQCV was found in eleven tissues including wings, legs, antennae, brain, fat bodies, salivary glands, gut, hemolymph, nerves, trachea, and food glands. However, BQCV PCR signal was not detected in the compound eyes. The intensity of the BQCVspecific band seen on agarose gel electrophoresis was relatively stronger in tissues of the brain, fat bodies, and gut compared to other tissues examined (Figure 1), indicating a higher level of infection in these tissues. For $B$. huntii workers reared in the lab, BQCV was detected in six tissues, including the legs, antennae, brain, fat bodies, salivary glands, and gut. For $B$. huntii males reared in the lab, BQCV was found in three tissues including the gut, nerves, and trachea (Table I).
While BQCV was detected in different tissues of bumble bees, the negative strand RNA of BQCV, indicative of virus replication, was only detected in the gut of $B$. huntii males from the field, and $B$. huntii workers and males reared in the lab (Figure 2, Table I).

A phylogenetic tree based on the sequences at the 3'UTR of the BQCV genome was constructed to illustrate the phylogenetic relationship of the BQCVs from B. huntii and $A$. mellifera originating from different countries. The percentage of similarity between BQCV from hosts of $B$. huntii and $A$. mellifera was from $80 \%$ to $98 \%$. The BQCVs from $B$. huntii collected from the field and reared in the lab were clustered closer to BQCV from the U.S. population of $A$. mellifera, compared to strains of BQCV from other regions of the world. The BQCVs from $B$. huntii appeared to be the most distantly related to the strain of BQCV from Jordan in the phylogenetic tree (Figure 3).

\section{DISCUSSION}

In nature, pathogens have evolved sophisticated mechanisms to exploit new hosts to expand their ecological niche, so that many pathogens infecting multiple host species is a common phenomenon. When pathogens cross a species barrier to spread in new hosts, the interspecies transmission of pathogens may result in the emergence of new diseases in animals. Here, we provide the first evidence that BQCV, one of the most prevalent honey bee viruses, could cause an infection in both laboratory-reared and field-collected bumble bees, B. huntii. While overt clinical signs of BQCV infection did not appear, our results demonstrate that the infection of BQCV could spread throughout the body of $B$. huntii males and workers, including tissues of appendages, the respiratory system, nervous system, digestive system, and circulatory system, likely a consequence of dissemination of the virus from the primary infection site (gut) to the secondary sites in the body via hemolymph.

Previous studies found elevated levels of the pathogens, microsporidian parasite, Nosema 


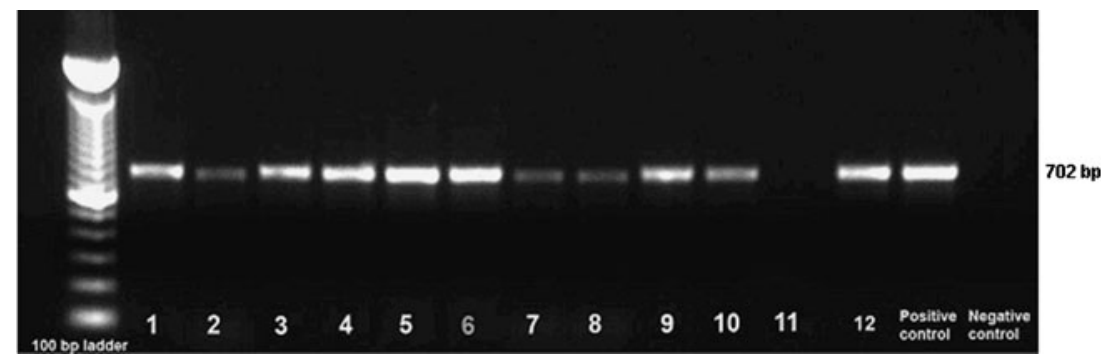

Figure 1. Detection of BQCV in different tissues of field-collected bumble bees. Conventional RT-PCR was performed and a 702-bp band indicating the BQCV infection is seen in 12 different tissues including: 1 wings, 2 legs, 3 antennae, 4 brain, 5 fat bodies, 6 gut, 7 salivary glands, 8 hemolymph, 9 nervous systems, 10 trachea, 11 eyes, and 12 food glands. Negative $\left(\mathrm{H}_{2} \mathrm{O}\right)$ and positive controls were included in the assay. A 100-bp ladder was included in the first lane of the gel.

bombi and the trypanosome Crithida bombi in the bumble bees used in greenhouse pollination relative to wild bees in the surrounding environment (Colla et al. 2006; Otterstatter and Thomson 2008). The results suggested that $N$. bombi and C. bombi were accumulated in the bumble bee rearing process and would "spillover" to wild populations if bees escaped from the greenhouse and interacted with the wild bees. However, our studies with BQCV showed that the infection of the BQCV was more widespread in the body of bumble bees collected from the field than that of indoor-reared bumble bees. A previous study (Chen et al. 2006) demonstrated that several honey bee viruses, including $\mathrm{BQCV}$, could be found in comb-stored pollen in honey bee colonies and that BQCV could be spread in the body of

Table I. Presence of bee viruses in the tissues of the $B$. huntii by RT-PCR assay.

\begin{tabular}{|c|c|c|c|c|c|c|}
\hline \multirow[t]{2}{*}{ Tissues } & \multicolumn{2}{|c|}{ Males caught } & \multicolumn{2}{|c|}{ Males reared } & \multicolumn{2}{|c|}{ Workers reared } \\
\hline & $\begin{array}{l}\text { Positive } \\
\text { strand }\end{array}$ & $\begin{array}{l}\text { Negative } \\
\text { strand }\end{array}$ & $\begin{array}{l}\text { Positive } \\
\text { strand }\end{array}$ & $\begin{array}{l}\text { Negative } \\
\text { strand }\end{array}$ & $\begin{array}{l}\text { Positive } \\
\text { strand }\end{array}$ & $\begin{array}{l}\text { Negative } \\
\text { strand }\end{array}$ \\
\hline 1 Wings & + & - & - & - & - & - \\
\hline 2 Legs & + & - & - & - & + & - \\
\hline 3 Antennae & + & - & - & - & + & - \\
\hline 4 Brain & + & - & - & - & + & - \\
\hline 5 Salivary gland & + & - & - & - & + & - \\
\hline 6 Gut & + & + & + & + & + & + \\
\hline 7 Fat bodies & + & - & - & - & + & - \\
\hline 8 Hemolymph & + & - & - & - & - & - \\
\hline $\begin{array}{l}9 \text { Nervous } \\
\text { systems }\end{array}$ & + & - & + & - & - & - \\
\hline 10 Trachea & + & - & + & - & - & - \\
\hline $\begin{array}{l}11 \text { Compound } \\
\text { eyes }\end{array}$ & - & - & - & - & - & - \\
\hline 12 Food gland & + & - & - & - & - & - \\
\hline
\end{tabular}




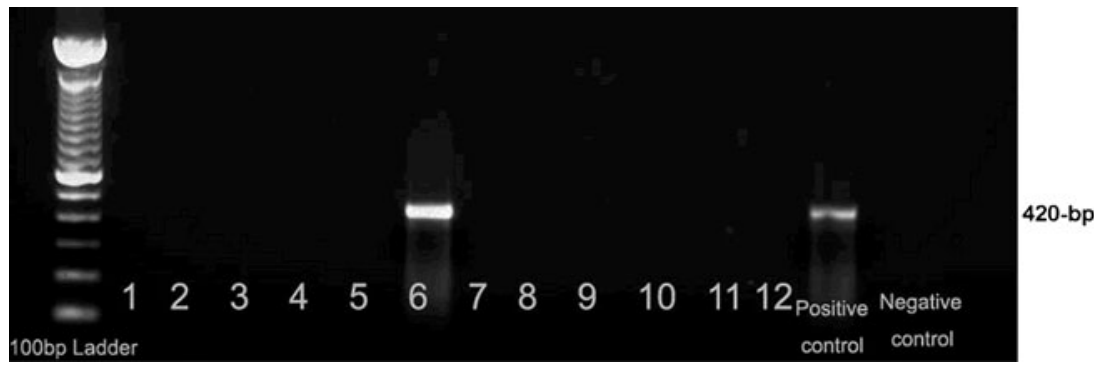

Figure 2. Detection of negative strand RNA of BQCV in different tissues of field-collected bumble bees. Strand-specific RT-PCR was performed in 12 different tissues including: 1 wings, 2 legs, 3 antennae, 4 brain, 5 salivary gland, 6 gut, 7 fat bodies, 8 hemolymph, 9 nervous systems, 10 trachea, 11 eyes, and 12 food gland. A 420-bp band indicates the presence of negative strand RNA of BQCV. Negative $\left(\mathrm{H}_{2} \mathrm{O}\right)$ and positive controls were included in the RT-PCR. A 100-bp DNA ladder was included in the first lane of the gel.

honey bees via a food-borne transmission pathway. In nature, bumble bees share nectar and pollen resources with honey bees which represents ample opportunity for bumble bees to pick up the same pathogens as honey bees via ingestion of virus-contaminated food. The observation of a more widely distributed infection of BQCV throughout the body of field-collected bumble bees in comparison to indoor-reared bees indicated that BQCV infections tended to be more intense in the bumble bee populations foraging outside in the field. Further, a more

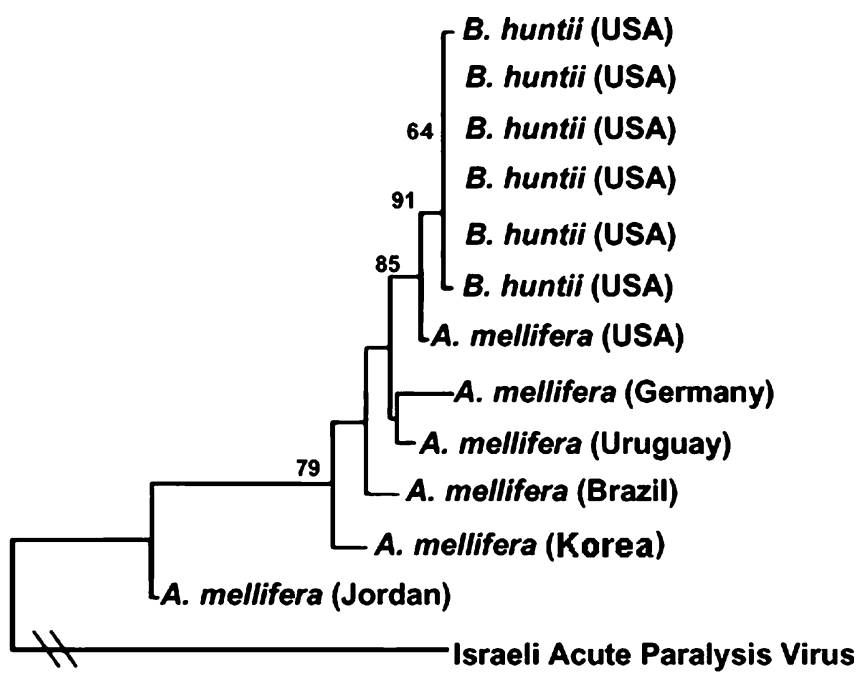

-1 change

Figure 3. Phylogenetic tree showing the relationship between BQCV from bumble bees and honey bees from different geographic locations. The sequences of BQCV from bumble bees in the present study were compared with the sequences of BQCV from honey bees retrieved from GenBank and originating from different countries were used to produce the phylogenetic tree. Phylogenetic analysis was conducted using ClustalW and neighborjoining algorithm. Numbers in the nodes correspond to bootstrap values. The scale bar represents 0.1 substitutions per nucleotide site. 
widespread distribution of BQCV in the body of indoor-reared workers than indoor-reared males, which forage less than workers, implies a possible association between the occurrence of virus transmission and foraging activities of bumble bees. The fact that lab-reared bumble bees were infected indicates that the virus is likely being introduced to the bumble bee colonies through feeding, or is present in the wild-caught queens used to initiate the nests in the spring. If food is responsible for the introduction, then it is most likely brought into the colony with the pollen since the sugar solution fed to the bees was sterilized. Because the pollen is sourced from pollen traps in honey bee colonies, this seems to be a likely route of introduction of the virus.

Replication and spread of viruses within tissues are essential steps for the successful establishment of viral infections. BQCV is a positive-stranded RNA virus and belongs to the virus family Dicistroviridae (Chen and Siede 2007). Like any other positive strand RNA viruses, the replication of the BQCV involves a replicative intermediate RNA, a negativestranded RNA that is complementary to positive-stranded RNA genomes and serves as templates for replication of nascent positive single-stranded RNA molecules for producing progeny viruses. Therefore, the presence of negative strand RNA of the BQCV would indicate active replication of the virus in the infected hosts. While BQCV was detected in different tissues of bumble bees, the negative strand RNA of BQCV was only found in the gut of $B$. huntii from both field and lab-reared colonies. To establish a successful infection in a host following along with the intake of food, the virus must replicate within the gut and then cross the gut lining into the hemolymph and circulate via the hemolymph to other tissues. While our results showed that BQCV could exit the gut following primary infection and disseminate to different tissues, the digestive tract of bumble bees was the only site of active BQCV replication. Other tissues appeared as sites of persistent $\mathrm{BQCV}$ infection without detectable virus replication. The replication of a viral pathogen in a host is a complex process involving many host-pathogen interactions. It is unclear what molecular mechanisms BQCV has that could thwart the host's immune response to replicate in the gut to establish infection and persist in the tissues of bumble bees. Further studies of the host-pathogen interactions and virus pathogenesis in bumble bees as well as the virus infective status of queens will shed light on the molecular basis of virus interspecies transmission and the mechanism that enables BQCV to adapt to a new host, thereby leading to the development of new control strategies for disease.

The finding that BQCV from the US population of bumble bees is phylogenetically close to the BQCV identified in the US population of honey bees suggests that geographical proximity between the two hosts also played a role in the host range expansion of BQCV. It has been previously suggested (Davis and Pedersen 2008) that pathogens more commonly expand their host range to closely related species (e.g., bumble bees and honey bees) than distantly related species. The similar physiological and genetic characteristics of host species are relatively easy for pathogens to adapt to the new environment. The mobility of bee pathogens across the species barriers has been documented by the detection of viruses and Nosema spp. in multiple species of the host (Bailey and Gibbs 1964; Anderson 1991; Niwa et al. 2004; Genersch et al. 2006; Plischuk et al. 2009). In general, the assumption is that the pathogens have moved from honey bee hosts to bumble bees, but in most cases it is unclear if that directionality is real. It may be that these pathogens are widely distributed in nature and because our knowledge of honey bee pathology is more advanced, we detect the pathogens first in Apis, then later, upon investigation, in Bombus.

\section{ACKNOWLEDGEMENTS}

This work was funded by the Chinese "948" Ministry of Agriculture Project (no. 2006-G19(4), Chinese National Natural Science Foundation for Young Scholars (no. 30700606, no. 30972149), International joint research project (no. 2009DFA32600) and an USDA-CAP grant (2009-85118-05718). 
Virus de la cellule noire de reine: extension de son spectre d'hôtes de l'abeille vers le bourdon Bombus huntii

spectre d'hôtes / bourdon / abeille / BQCV / transmission virale

\section{Erweiterung des Wirtsspektrums des Black Queen Cell Virus auf die Hummel Bombus huntii}

\author{
Wirtsspektrum / Hummel / Bombus huntii / Black \\ queen cell virus
}

\section{REFERENCES}

Anderson, D.L. (1991) Kashmir bee virus - a relatively harmless virus of honey bee colonies. Am. Bee J. 131, 767-770

Anderson, D.L. (1993) Pathogens and queen bees. Australas. Beekeep. 94, 292-296

Bailey, L., Gibbs, A.J. (1964) Acute infection of bees with paralysis virus. J. Insect Pathol. 6, 395-407

Bailey, L., Woods, R.D. (1977) Two more small RNA viruses from honey bees and further observations on sacbrood and acute bee-paralysis viruses. J. Gen. Virol. 37, 175-182

Benjeddou, M., Leat, N., Allsopp, M., Davison, S. (2001) Detection of acute bee paralysis virus and black queen cell virus from honeybees by reverse transcriptase PCR. Appl. Environ. Microbiol. 67, 2384-2387

Boncristiani Jr., H.F., Di Prisco, G., Pettis, J.S., Hamilton, M., Chen, Y.P. (2009) Molecular approaches to the analysis of deformed wing virus replication and pathogenesis in the honey bee, Apis mellifera. Virol. J. 6, 221-230

Brown, M.J.F., Schmid-Hempel, R., Schmid-Hempel, P. (2003) Strong context-dependent virulence in a hostparasite system: reconciling genetic evidence with theory. J. Anim. Ecol. 72, 994-1002

Cameron, S.A., Lozier, J.D., Strange, J.P., Koch, J., Cordes, B.N., Solter, L.F., Griswold, T.L. (2011) Patterns of widespread decline in North American bumble bees. Proc. Nat. Acad Sci USA 108, 662667

Chen, Y.P., Siede, R. (2007) Honey bee viruses. Adv. Virus Res. 70, 33-80

Chen, Y.P., Evans, J.D., Feldlaufer, M.F. (2006) Horizontal and vertical transmission of viruses in the honey bee, Apis mellifera. J. Invertebr. Pathol. 92, 152-159

Chenna, R., Sugawara, H., Koike, T., Lopez, R., Gibson, T.J., Higgins, D.G., Thompson, J.D. (2003) Multiple sequence alignment with the Clustal series of programs. Nucleic Acids Res 31, 3497-3500

Colla, S.R., Otterstatter, M.C., Gegear, R.J., Thomson, J. D. (2006) Plight of the bumble bee: Pathogen spillover from commercial to wild populations. Biol. Conserv. 129, 461-467

Davis, T.J., Pedersen, A.B. (2008) Phylogeny and geography predict pathogen community similarity in wild primates and humans. Proc. R. Soc. B 275, 1695-1701

Dohzond, I., Yokoyama, J. (2010) Impact of alien bees on native plant-pollinator relationships: a review with special emphasis on plant reproduction. Appl. Entomol. Zool. 45, 37-47

Evans, E., Spivak, M. (2006) Effects of honey bee (Hymenoptera: Apidae) and bumble bee (Hymenoptera: Apidae) presence on cranberry (Ericales: Ericaceae) pollination. J. Econ. Entomol. 99, 614-620

Genersch, E., Yue, C., Ingemar, F., de Mirandac, J.R. (2006) Detection of deformed wing virus, a honey bee viral pathogen, in bumble bees (Bombus terrestris and Bombus pascuorum) with wing deformities. J. Invertebr. Pathol. 91, 61-63

Heinrich, B. (2004) Bumblebee Economics, 2nd edn. Harvard University Press, Cambridge, Massachusetts

Hobbs, G.A. (1967) Ecology of species of Bombus (Hymenoptera: Apidae) in southern Alberta. VI. subgenus Pyrobombus. Can. Entomol. 99, 1271-1292

Leat, N., Ball, B., Govan, V., Davison, S. (2000) Analysis of the complete genome sequence of black queen-cell virus, a picorna-like virus of honey bees. J. Gen. Virol. 81, 2111-2119

Mayo, M.A. (2002) Virus taxonomy-Houston 2002. Arch. Virol. 147, 1071-1076

Niwa, S., Iwano, H., Asada, S., Matsuurra, M., Goka, K. (2004) A microsporidian pathogen isolated from a colony of the European bumblebee, Bombus terrestris, and infectivity on Japanese bumblebee. Jap. J. Appl. Entomol. Zool. 48, 60-64

Otterstatter, M.C., Thomson, J.D. (2008) Does pathogen spillover from commercially reared bumble bees threaten wild pollinators? PLoS One 3, e2771

Plischuk, S., Raquel, Martín-Hernández R., Prieto, L., Lucía, M., Botías, C., Meana, A., Abrahamovich, A. H., Lange, C., Higes, M. (2009) South American native bumblebees (Hymenoptera: Apidae) infected by Nosema ceranae (Microsporidia), an emerging pathogen of honeybees (Apis mellifera). Environ. Microbiol. Rep. 1, 131-135

Proctor, M., Yeo, P., Lack, A. (1996) In The natural history of pollination, pp. 387-388. Timber Press Inc, Portland, OR

Reader, T., MacLeod, I., Elliott, T.P., Robinson, O.J., Manica, A. (2005) Inter-order interactions between flower-visiting insects: foraging bees avoid flowers previously visited by hoverflies. J. Insect. Behav. 18, 51-57. doi:10.1007/s10905-005-9346-8 
Schmid-Hempel, P. (2001) On the evolutionary ecology of host-parasite interactions - addressing the questions with bumblebees and their parasites. Naturwissenschaften 88, 147-158

Strange, J.P. (2011) Nest initiation in three North American bumble bees (Bombus): gyne number and presence of honey bee workers influence establishment success and colony size. J. Insect Sci. 10, 130. available online: insectscience.org/ 10.130
Velthuis, H.H.W., van Doorn, A. (2006) A century of advances in bumble bee domestication and the economic and environmental aspects of its commercialization for pollination. Apidologie 37, 421-451

Whitman, M. (2007) Humblebee Bumblebee. Wild Ones Journal, March/April issue

Yue, C., Genersch, E. (2005) RT-PCR analysis of deformed wing virus in honeybees (Apis mellifera) and mites (Varroa destructor). J. Gen. Virol. 86, 3419-3424 